\title{
ORGANISATION PATTERN OF MARTIN LUTHER KING JR'S ARGUMENTATIVE SPEECH
}

\author{
Diana Sopha \\ Fakultas Sastra, Universitas MuslimNusantara Al-Washliyah \\ sophadiana79@gmail.com
}

\begin{abstract}
Abstrak
Penelitian ini mengkaji pola susunan ide pada pidato argumentasi Martin Luther King Jr. Tujuan penelitian ini yaitu untuk mengidentifikasi jenis pola susunan ide yang digunakan dalam pidato argumentasinya dan untuk mengetahui bagaimana ide pro dan kontra disusun sehingga menghasilkan suatu pidato argumentasi yang dapat dipahami, menarik perhatian dan mempengaruhi publik. Melalui metode penelitian qualitatif deskriptif, diperoleh hasil penelitian bahwa pidato argumentasi tersebut menggunakan 2 pola susunan yaitu Thesis^ $\mathrm{CON}+$ Refutation^ PRO Idea^Conclusion dan pola susunan Thesis`PRO Idea^CON + Refutation^ Conclusion. Dengan demikian, ide dalam pidato tersebut disusun secara sistematis melalui tesis yang diikuti dengan ide pro atau kontra dan ditutup dengan kesimpulan. Selanjutnya, setiap ide pro dan kontra selalu didukung dengan contoh atau bukti untuk mendukung kebenaran ide yang disampaikan melalui pidato argumentasinya.
\end{abstract}

Kata kunci : pola susunan, pidato, argumentasi, Martin Luther King Jr.

\begin{abstract}
This research analyzes Organisation Pattern in Martin Luther Jr. It identifies the type of Organisation Pattern and how the pro and contra ideas are organized that will finally be able to be understood, attract and influence public. Using descriptive qualitative method, this research finds that two organisation pattern used: Thesis ${ }^{\wedge} \mathrm{CON}+$ Refutation ${ }^{\wedge} \mathrm{PRO}$ Idea^ Conclusion and organisation pattern Thesis^ PRO Idea^CON + Refutation ${ }^{\wedge}$ Conclusion. The ideas in the speech is organised systematically through Thesis, pro or contra ideas and conclusion. Then every pro and contra idea is always by example or prove to support the truth of the idea expressed through his argumentative speech.
\end{abstract}

Keywords : organisation pattern, speech, argumentation, martin luther king Jr.

\section{INTRODUCTION}

Delivering speech directly spoken or through a written text needs a compex skill or cempetence. It is not easy to create a writing which contains so many important ideas to be understood by others, especially to influence the people so they will finally agree and accept all the ideas delivered by the speakers/orators or writers. One of popular public political figures that had given much influence towards American people is Martin Luther King Jr.. He was a great orator who produced famous speeches. His speeches created many kinds of reaction like and dislike as reflected in his speeches that contains pro and contra arguments. Through his speeches in front of the public, he gave all of his arguments supported with logical and factual reasons so the public could accept all of his arguments that finally could support 
him to do struggle for liberty, equality and freedom.

Related to the speech delivered by Martin Luther King Jr. in argumentative text, as previously stated this text contains some pro and contra arguments as important informations to the listeners. These speakers or writers deliver their arguments in their own way related on some significant current issues in society. This research only concerns on pollitical argumentative speech. In these speeches, there are pro and contra arguments delivered to the listener that will be the discussion of this research.

The argumentative speech mainly discussed in this research is the organization of pattern. Organization of pattern is very significant as the strategy to arrange the ideas in correct order. The good technique of arranging ideas from one paragraph to other paragraphs will lead the text into its success in delivering ideas and influencing the listeners' point of view. The well arrangement of ideas in argumentative speech will make the listeners easy to understand the ideas and messages delivered in it.

\section{REVIEW OF LITERATURE}

\subsection{Argumentative Speech}

An argumentative speech is a persuasive speech in which the speaker attempts to persuade his audience to alter their viewpoints on a controversial issue. While a persuasive speech may be aimed more at sharing a viewpoint and asking the audience to consider it, an argumentative speech aims to radically change the opinions already held by the audience. This type of speech is extremely challenging; therefore, the speaker should be careful to choose a topic which he feels prepared to reinforce with a strong argument.

Argumentative speeches generally concern topics which are currently being debated by society, current controversial issues. These topics are often derived from political debates and issues which are commonly seen in the media. The chosen topic may be political, religious, social, or ethical in nature. The audience should be challenged to re-examine their long-held values, and will be asked to alter deeply held convictions based on new evidence or viewpoints on the issue. Obviously, selecting a topic that is debatable is key to create an effective speech. The topic should not be something which is generally already proven, or would require an enormous leap of faith or logic in order to convince the audience. The speaker should already possess a strong interest and have a deeplyheld opinion on the subject, or else his arguments will probably not come across as believable to the audience.

\subsection{The Organization Pattern in Argumentative Speech}

Based on Buowl

(http://www.buowl.boun.edu.tr/stude nts/types of essays/_Argumentative Essay) argumentative writing has some patterns of organization of idea. All argumentative topics have PROs and CONs. Before starting writing, it is imperative to make a list of these ideas and choose the most suitable ones among them for supporting and refuting.

There are three possible organization patterns:

Pattern 1: 
Thesis statement:

PRO idea 1

PRO idea 2

$\mathrm{CON}(\mathrm{s})+$ Refutation(s)

Conclusion

Pattern 2:

Pattern 3:

Thesis statement:

Thesis statement:

$\mathrm{CON}(\mathrm{s})+$ Refutation(s)

CON idea 1

$----->$

Refutation

PRO idea 1

CON idea 2

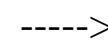

Refutation

PRO idea 2

CON idea 3

Refutation

Conclusion

Conclusion

Buowl

The example below is from

(http://www.buowl.boun.edu.tr/stude nts/types of essays/ Argumentative

Essay):

Thesis: Do Reiki instead of taking medicine.

Counter Arguments

1. People should trust medicine since it is effective and scientifically proven.

2. Serious illnesses such as HIV/AIDS and cancer cannot be treated without medicine.

3. Reiki, like alternative healing methods, requires a lot of time.

In creating argumentative text, there two important points to be concerned. First is the supporting ideas. This is the most important part when persuading others. We are asking some people to change their beliefs or actions. We should be supporting our ideas with such facts, statistics and/or authorities. Secondly is the Refuting opposing arguments. Before we start saying that the opponents are wrong, we should specify their opposing ideas. Otherwise, it would be like hitting the other person with eyes closed. We should see clearly what we are hitting and be prepared beforehand so that he cannot hit us back. We can do this by knowing what we are refuting (Buowl at http ://www. buowl. boun. edu.tr/students/types of essays/ Argumentative Essay) .

\subsection{METHODOLOGY Research Method}

Research is a systematic process of collecting and logically analyzing information (data) for some purpose. It is accurate investigation, observation and description. In fact, every research activity must be done accurately so that the findings will lead to the formulation of scientific generalization. All conclusions are based on actual evidence (Hartoyo,2010:3-9).

This rdRefinctation is using deReripitisedquarciatitieiaplpyquach.eThe descodiphies not haethoidle efféress a sy(stefintatiicon ifrecthrodl; insoudficienturate abodatnthe data (Djajasudarma, 1993). QMadidacine atsoecarnhotgines sexplisit deitlinlesteks striptidingfi okatd abblection anedarly stagen(ilefsisation methocedure

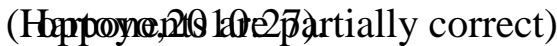

3.ReObjectuofethesResearidhlone regTiharl y.bjeeffutetiothenettrsedtrch is takppofirents angumempletety speeng) in written delivered by Martin Luther King Jr. There are two speeches discussed in this research: first is $I$ have a dream and the second is $A$ 
speech at Nobel Peace Prize Acceptance.

\subsection{Method of collecting Data}

The benefits of the qualitative approach is that the information is richer and has a deeper insight into the phenomenon under study. Qualitative research data collection methods are time consuming, therefore data is usually collected from a smaller sample than would be the case for quantitative approaches therefore this makes qualitative research more expensive (Libweb.survey.ac.uk/library/skill/Int roduction to Research and Managing Information Leic).

The method for collecting qualitative data is by observing data. The data is read and comprehended through skimming and scanning. The relation of one main idea of paragraph to another paragraph also becomes the concentration in reading and comprehending the organization of patterns in the speeches transcription.

\subsection{Technique of Analyzing Data}

The data of this research is analized through some phases. They are :

1) Classifying the main idea in each paragraph into pro or contra argument.

2) Determining the type of Organization Pattern

3) Discussing the use of Organization Pattern

4) Drawing conclusions.

\section{RESULT AND DISCUSSION \\ 4.1 Results}

Based on the result of analysis in Martin Luther King Jr.'s argumentative speech, there are two types of organization patterns used in his speech.

The first speech "I Have a Dream" by Martin Luther King Jr. uses the second pattern of organization pattern:

\section{Pattern 2:}

Thesis statement:

CON(1) + Refutation(1)

$\mathrm{CON}(2)+$ Refutation(2)

CON(3) + Refutation(3)

PRO idea 1

PRO idea 2

PRO idea 3

PRO idea 4

PRO idea 5

PRO idea 6

PRO idea 7

PRO idea 8

PRO idea 9

Conclusion

Different from the speech " I Have a Dream", The speech at Nobel Prize Acceptence uses two combinations of organisation of pattern (Pattern one and two) :

\section{Pattern 1 and Pattern 2:}

Thesis statement:

PRO idea 1

$\mathrm{CON}(\mathrm{s})+$ Refutation(s)

PRO idea 2

PRO idea 3

PRO idea 4

PRO idea 5

PRO idea 6

PRO idea 7

PRO idea 8

Conclusion

\subsection{Discussions}

The speech "I Have a Dream" by Martin Luther King Jr. uses the second pattern of organization pattern as discussed below: 
Thesis Statement : The greatest demonstration for freedom in the history of nation.

Table 1 : Organisation Pattern of the Speech "I Have a Dream"

\begin{tabular}{|c|c|c|}
\hline No. & Counter Arguments & Refutation \\
\hline 1 & $\begin{array}{l}\text { The emancipation was signed } \\
\text { as the end of Negro slavery }\end{array}$ & The Negro slavery is still continued \\
\hline 2 & $\begin{array}{l}\text { The promissory note was } \\
\text { written as the declaration that } \\
\text { all men have the same rights }\end{array}$ & The promissory note is extinct or forgotten \\
\hline \multirow[t]{2}{*}{3} & $\begin{array}{l}\text { America gives a check } \\
\text { 'insufficient fund' }\end{array}$ & $\begin{array}{l}\text { The check 'insufficient fund' is refused because it can } \\
\text { still be cashed to get back freedom and justice. }\end{array}$ \\
\hline & Suppporting Ideas & Reasons to support the ideas \\
\hline 4 & $\begin{array}{l}\text { Now is the time to act (to do } \\
\text { all : peace, democracy, equal } \\
\text { rights and justice) }\end{array}$ & $\begin{array}{l}\text { Because now is the time : } \\
-\quad \text { to make real the promises of democracy } \\
-\quad \text { to rise from the dark and desolate valley of } \\
\text { segregation to the sunlit path of racial justice. } \\
\text { - } \\
\text { to lift our nation from the quicksands of racial } \\
\text { injustice to the solid rock of brotherhood. } \\
\text { - } \\
\text { to make justice a reality for all of God's } \\
\text { children. }\end{array}$ \\
\hline 5 & $\begin{array}{l}\text { The old season is ended and } \\
\text { now is the new season of } \\
\text { freedom and equality }\end{array}$ & $\begin{array}{l}\text { This sweltering summer of the Negro's legitimate } \\
\text { discontent will not pass until there is an invigorating } \\
\text { autumn of freedom and equality. }\end{array}$ \\
\hline 6 & $\begin{array}{l}\text { Negro's struggle has never } \\
\text { end till they get their rights. }\end{array}$ & $\begin{array}{l}\text { This time is a beginning for the Negro to blow off } \\
\text { steam, to have a rude awakening and to get his } \\
\text { citizenship rights. }\end{array}$ \\
\hline 7 & $\begin{array}{l}\text { The negro people has suffered } \\
\text { much violence so stop doing } \\
\text { all the violence }\end{array}$ & $\begin{array}{l}\text { We must forever conduct our struggle on the high } \\
\text { plane of dignity and discipline. We must not allow our } \\
\text { creative protest to degenerate into physical violence. } \\
\text { We must rise to the majestic heights of meeting } \\
\text { physical force with soul force. }\end{array}$ \\
\hline 8 & $\begin{array}{l}\text { The white people should be } \\
\text { together with the negro people } \\
\text { to build the nation }\end{array}$ & $\begin{array}{l}\text { Their destiny (white people) is tied up with our } \\
\text { destiny. And they have come to realize that their } \\
\text { freedom is inextricably bound to our freedom. We } \\
\text { cannot walk alone. And as we walk, we must make the } \\
\text { pledge that we shall always march ahead. }\end{array}$ \\
\hline 9 & $\begin{array}{l}\text { The negro people never give } \\
\text { up till they get the freedom } \\
\text { and equality }\end{array}$ & $\begin{array}{l}\text { We can never be satisfied as long as } 1 \text { ) the Negro is } \\
\text { the victim of the unspeakable horrors of police } \\
\text { brutality 2) our bodies, heavy with the fatigue of } \\
\text { travel, cannot gain lodging in the motels of the } \\
\text { highways and the hotels of the cities, } 3 \text { ) the negro's } \\
\text { basic mobility is from a smaller ghetto to a larger one, } \\
\text { 4) our children are stripped of their self-hood and } \\
\text { robbed of their dignity by signs stating: "For Whites } \\
\text { Only" 5) a Negro in Mississippi cannot vote 6) until } \\
\text { "justice rolls down like waters, and righteousness like } \\
\text { a mighty stream." }\end{array}$ \\
\hline 10 & $\begin{array}{l}\text { All the black people who } \\
\text { suffered a lot must not stop } \\
\text { and keep struggling wherever } \\
\text { they are) }\end{array}$ & $\begin{array}{l}\text { Continue to work with the faith that unearned suffering } \\
\text { is redemptive. Go back to Mississippi, go back to } \\
\text { Alabama, go back to South Carolina, go back to } \\
\text { Georgia, go back to Louisiana, go back to the slums } \\
\text { and ghettos of our northern cities, knowing that } \\
\text { somehow this situation can and will be changed. }\end{array}$ \\
\hline 11 & $\begin{array}{l}\text { People should never give up } \\
\text { till they make their dreams }\end{array}$ & $\begin{array}{l}\text { I have a dream that one day this nation will rise up and } \\
\text { live out the true meaning of its creed: "We hold these }\end{array}$ \\
\hline
\end{tabular}




\begin{tabular}{|c|c|c|}
\hline & come true & $\begin{array}{l}\text { truths to be self-evident, that all men are created } \\
\text { equal." }\end{array}$ \\
\hline \multirow[t]{2}{*}{12} & $\begin{array}{l}\text { People should have hope and } \\
\text { faith in doing struggle }\end{array}$ & $\begin{array}{l}\text { With this faith, we will be able to 1) hew out of the } \\
\text { mountain of despair a stone of hope } 2 \text { ) transform the } \\
\text { jangling discords of our nation into a beautiful } \\
\text { symphony of brotherhood, 3) work together, to pray } \\
\text { together, to struggle together, to go to jail together, to } \\
\text { stand up for freedom together, knowing that we will be } \\
\text { free one day. }\end{array}$ \\
\hline & Conclusion & Main Messages \\
\hline 13 & $\begin{array}{l}\text { People should sing the } \\
\text { freedom together and speak } \\
\text { the freedom to the world. }\end{array}$ & $\begin{array}{l}\text { This will be the day when all of God's children will be } \\
\text { able to : } \\
\text { - } \text { sing with new meaning } \\
\text { - } \quad \text { allow freedom ring } \\
\text { - let it ring from every village and every } \\
\text { hamlet, from every state and every city } \\
\text { - } \text { speed up that day when all of God's children, } \\
\text { black men and white men, Jews and Gentiles, } \\
\text { Protestants and Catholics, will be able to join } \\
\text { hands and sing in the words of the old Negro } \\
\text { - } \text { spiritual } \\
\text { be free at last. }\end{array}$ \\
\hline
\end{tabular}

After discussing the second pattern used in Martin Luther King Jr.'s speech "I have a dream", the next speech is delivered at Nobel Peace Prize Acceptance. This speech uses two combinations of organisation of pattern : Pattern one and two as discussed in the table below:

\section{Thesis Statement : The reasons of the noble prize are accepted}

Table 2: Organisation Pattern of the Speech at Nobel Peace Prize Acceptance

\begin{tabular}{|c|c|c|}
\hline No. & Supporting Ideas & Reasons to support the ideas \\
\hline \multirow[t]{2}{*}{1} & $\begin{array}{l}\text { Remembering and memorizing the } \\
\text { past suffering }\end{array}$ & $\begin{array}{l}\text { - yesterday in Birmingham, Alabama, our } \\
\text { children, crying out for brotherhood } \\
\text { - in Philadelphia, Mississippi, young people } \\
\text { seeking to secure the right to vote were } \\
\text { brutalized and murdered. } \\
\text { only yesterday more than } 40 \text { houses of worship } \\
\text { in the State of Mississippi alone were bombed } \\
\text { or burned because they offered a sanctuary to } \\
\text { those who would not accept segregation. }\end{array}$ \\
\hline & Counter Argument & Refutation \\
\hline \multirow[t]{2}{*}{2} & $\begin{array}{l}\text { The awarding of the Noble Prize is } \\
\text { for the successful movement in } \\
\text { achieving the world peace. }\end{array}$ & $\begin{array}{l}\text { Why this prize is awarded to : } \\
\text { - } \text { a movement which is beleagured and committed } \\
\text { - to unrelenting struggle; } \\
\text { a movement which has not won the very peace } \\
\text { and brotherhood which is the essence of the } \\
\text { Nobel Prize. }\end{array}$ \\
\hline & Supporting ideas & Reasons to support the idea \\
\hline 3 & $\begin{array}{l}\text { The real meaning of Noble Prize } \\
\text { Award is brotherhood, peace with no } \\
\text { violence } \quad \text { anymore }\end{array}$ & $\begin{array}{l}\text { I receive on behalf of that movement is a profound } \\
\text { recognition that nonviolence is the answer to the crucial } \\
\text { political and moral question of our time - - the need for } \\
\text { man to overcome oppression and violence without } \\
\text { resorting to violence and oppression. }\end{array}$ \\
\hline 4. & $\begin{array}{l}\text { The negros struggled across many } \\
\text { regions in America to find the } \\
\text { justice } \\
\text { for }\end{array}$ & $\begin{array}{l}\text { The tortuous road which has led from Montgomery, } \\
\text { Alabama, to Oslo bears witness to this truth. This is a road } \\
\text { over which millions of Negroes are travelling to : } \\
\text { - } \quad \text { find a new sense of dignity }\end{array}$ \\
\hline
\end{tabular}




\begin{tabular}{|c|c|c|}
\hline & & $\begin{array}{ll}\text { - } & \text { opened for all Americans a new era of progress } \\
& \text { and hope } \\
\text { - } & \text { a new Civil Rights Bill } \\
\text { - } & \text { a super highway of justice as Negro and white } \\
\text { men in increasing numbers create alliances to } \\
\text { overcome their common problems. }\end{array}$ \\
\hline 5 & Luther refused all the injustice & $\begin{array}{l}\text { I refuse to accept despair as the final response to the } \\
\text { ambiguities of history. }\end{array}$ \\
\hline 6. & $\begin{array}{l}\text { Luther believed that there will be a } \\
\text { better fate for Negros }\end{array}$ & $\begin{array}{l}\text { I believe that unarmed truth and unconditional love will } \\
\text { have the final word in reality. }\end{array}$ \\
\hline 7. & $\begin{array}{l}\text { People should have faith to struggle } \\
\text { in the future }\end{array}$ & 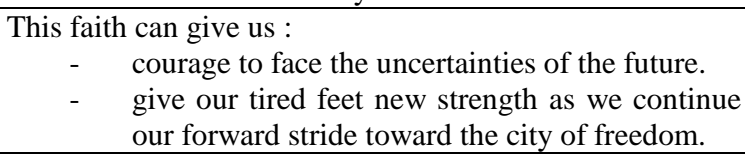 \\
\hline 8 & $\begin{array}{l}\text { The Noble Prize is not for personal } \\
\text { but as the representative of all the } \\
\text { people who struggle for humanity, } \\
\text { love and freedom }\end{array}$ & $\begin{array}{l}\text { The reasons to accept the prize : } \\
\text { - as a trustee, inspired and with renewed } \\
\text { dedication to humanity. } \\
\text { - on behalf of all men who love peace and } \\
\text { brotherhood. } \\
\text { - } \quad \text { as a trustee, for in the depths of my hear! } \\
\text { - for much more than an honor personally. }\end{array}$ \\
\hline \multirow[t]{2}{*}{9} & $\begin{array}{l}\text { People should honour all those men } \\
\text { who struggled for freedom }\end{array}$ & $\begin{array}{l}\text { - they have sat at the controls as the freedom } \\
\text { movement soared into orbit. } \\
\text { - Chief Lutuli of South Africa, whose struggles } \\
\text { with and for his people, } \\
\text { the ground crew without whose labor and } \\
\text { sacrifices the jet flights to freedom could never } \\
\text { have left the earth. } \\
\text { these humble children of God were willing to } \\
\text { suffer for righteousness sake. }\end{array}$ \\
\hline & Conclusion & The Main Message \\
\hline 10. & $\begin{array}{l}\text { The main reasons of Alfred Noble } \\
\text { Prize Awards are for brotherhood } \\
\text { and peace }\end{array}$ & $\begin{array}{l}\text { I accept this award in the spirit of a curator of some } \\
\text { precious heirloom which he holds in trust for its true } \\
\text { owners - all those to whom beauty is truth and truth } \\
\text { beauty - and in whose eyes the beauty of genuine } \\
\text { brotherhood and peace is more precious than diamonds or } \\
\text { silver or gold. }\end{array}$ \\
\hline
\end{tabular}

\section{CONCLUSIONS}

Based on the result of the research of organisation of pattern in Martin Luther King Jr.'s Argumentative speech, the conclusions are:

1. the speech "I Have a Dream" is using Pattern 2 of Organisation Pattern and "the Speech at Nobel Prize Acceptance" is using the combination of two patterns: pattern one and two of organisation pattern.

2. The organisation pattern in Martin Luther King Jr.'s Argumentative speech is using :
a. Thesis Statement

b. Counter + Refutation

c. Supporting Ideas

d. Conclusion.

These four elements are organized variedly. First, by organizing Counter arguments + Refutation before Supporting Ideas and by organizing Counter arguments + Refutation after and before Supporting Ideas (Counter argument + Refutation is among Supporting Ideas). 


\section{REFERENCES}

Buowl.

http://www.buowl.boun.edu.tr/st udents/types of essays/ Argumentative

Essay.htm.accessed on March $29^{\text {th }}, 2017$ at $04.30 \mathrm{pm}$.

Djajasudarma, Fatimah.1993.

Metode Linguistik : Ancangan Metode Penelitian dan Kajian. Bandung : Eresco.

Dlugan,Andrew.http//www sixminutes.dlugan.com/speechanalysis-dream-martin-lutherking/ accessed on March 30, 2017 at 09.00 am.

Glass,

Kathy.2014. Argumentation:Characteristic s, Assessments, and Lesson ideas (A Lecture Handout). Nashvile.

Hartoyo.2010. Research in

Education (Compilation).

Fakultas Bahasa dan Seni-

Universitas Negeri Semarang.

http//www.nobelprize.org/nobel_priz es/peace/laureates/1964/kingbio.html. accessed on March 30, 2017 at $11.30 \mathrm{am}$.

Libweb.survey.ac.uk/library/skill/Int roduction to Research and Managing Information Leic

McWhorter, Kathleen T. Reading Across the Disciplines. $2 \mathrm{Nd}$ Ed. New York: Pearson Longman, 2005 at http $\mathrm{s}$ : / /valenciacollege. Edu /wp /cssc documents

/organizationalPatternsinAcade micWriting.pd

Pardiyono. 2007. Teaching Genre Based Writing. Yogyakarta: Andi.

Ursula Wingate. 2011.'Argument!' helping students understand what essay writing is about. www. Elseviere.com/locate/jeap.
Accessed on august 23, 2017 at 10.45 . 